University of Nebraska - Lincoln

DigitalCommons@University of Nebraska - Lincoln

1986

\title{
EFFECT OF ACTIVE IMMUNIZATION AGAINST LHRH OR LH IN BOARS: REPRODUCTIVE CONSEQUENCES AND PERFORMANCE TRAITS
}

R. E. Falvo

Southern Illinois University

V. Chandrashekar

Southern Illinois University

R. D. Arthur

Southern Illinois University

A. R. Kuenstler

Southern Illinois University

T. Hasson

Southern Illinois University

See next page for additional authors

Follow this and additional works at: https://digitalcommons.unl.edu/usdaarsfacpub

Part of the Agricultural Science Commons

Falvo, R. E.; Chandrashekar, V.; Arthur, R. D.; Kuenstler, A. R.; Hasson, T.; Awcniyi, C.; and Schanbacher, B. D., "EFFECT OF ACTIVE IMMUNIZATION AGAINST LHRH OR LH IN BOARS: REPRODUCTIVE CONSEQUENCES AND PERFORMANCE TRAITS" (1986). Publications from USDA-ARS / UNL Faculty. 772. https://digitalcommons.unl.edu/usdaarsfacpub/772

This Article is brought to you for free and open access by the U.S. Department of Agriculture: Agricultural Research Service, Lincoln, Nebraska at DigitalCommons@University of Nebraska - Lincoln. It has been accepted for inclusion in Publications from USDA-ARS / UNL Faculty by an authorized administrator of DigitalCommons@University of Nebraska - Lincoln. 


\section{Authors}

R. E. Falvo, V. Chandrashekar, R. D. Arthur, A. R. Kuenstler, T. Hasson, C. Awcniyi, and B. D. Schanbacher 


\title{
EFFECT OF ACTIVE IMMUNIZATION AGAINST LHRH OR LH IN BOARS: REPRODUCTIVE CONSEOUENCES AND PERFORMANCE TRAITS ${ }^{1}$
}

\author{
R. E. Falvo ${ }^{2,3}$, V. Chandrashekar ${ }^{3}$, R. D. Arthur ${ }^{4}$, A. R. Kuenstler ${ }^{4}$, T. Hasson ${ }^{3}$, \\ C. Aweniyi ${ }^{3}$ and B. D. Schanbacher ${ }^{5}$ \\ Southern Illinois University, Carbondale 62901 \\ and \\ U.S. Department of Agriculture, Clay Center, NE 68933
}

\begin{abstract}
Forty crossbred boars were equally divided into eight groups at birth. Four groups were immunized (200 $\mu \mathrm{g} / \mathrm{boar}$ ) at $12 \mathrm{wk}$ of age against either luteinizing hormone-releasing hormone (LHRH) conjugated to human serum globulin (LHRH-hSG) in complete Freund's adjuvant (CFA), LHRH-hSG in muramyldipeptide adjuvant (PEP), procine luteinizing hormone (LH) conjugated to hSG (pLH-hSG) in CFA or ovine LH (oLH) in CFA. Equal doses of boosters were given in either PEP or incomplete Freund's adjuvant (IFA) at 16 and $18 \mathrm{wk}$ of age. Two groups of boars were immunized with either hSG + CFA or hSG + PEP (adjuvant controls). Two groups were castrated either at the time of weaning (castrate weaning) or at $16 \mathrm{wk}$ when immunized boars were given their first booster injections (castrate booster). All pigs were slaughtered at 24 wk of age. Serum levels of LH and testosterone (T), LHRH or LH antibody titers, as well as testicular and accessory sex gland weights and histology were determined. By wk 16, LHRH antibody titers began to rise in those boars immunized against LHRH-hSG. Luteinizing hormone-releasing hormone antibody titers on wk 18, 20 and 22 were greater than those at wk 16. By 22 wk of age, LHRH-hSG boars had non-detectable plasma $L H$ and $T$ and reduced weights of testes and acessory sex glands. Boars immunized against oLH did not respond to treatment, whereas pLH-hSG boars showed a reduction in serum $T$ levels and accessory sex gland weights. Immunization had no effect on average daily gain, hot carcass weights or loin eye area. Animals immunized against LHRH in CFA had increased 10th rib fat $(P<.05)$ when compared with the castrated controls, adjuvant controls and the pLH-immunized boars. The incidence of boar taint was reduced $(P<.05)$ in the L.HRH-hSG and pLH-treated boars. We conclude that LHRH immunoneutralization resulted in castration-like carcass effects in boars but had no effect on performance characteristics, with the possible exception of backfat thickness. These data demonstrate for the first time that active immunization against LHRH is both feasible and practical as an alternative to surgical castration in boars.

(Key Words: Boars, Castration, LHRH, LH, Testosterone, Boar Taint.)
\end{abstract}

\section{Introduction}

More efficient and leaner carcass production in the swine industry has been emphasized because of the declining demand for pork fat and the increasing demand for lean meat.

\footnotetext{
${ }^{1}$ Supported in part by the Natl. Pork Producers Assoc., Acknowledgment is made to the USDA and NIAMDD for gifts of porcine and ovine LH used in this study. We also thank G. D. Niswender for the porcine LH radioimmunoassay materials.

${ }^{2}$ Reprint requests: Dr. Richard E. Falvo, Dept. of Physiol., School of Med., Lindegren Hall, Southern Illinois Univ., Carbondale, IL 62901.

${ }^{3}$ Dept. of Physiol., School of Med.

${ }^{4}$ Dept. of Anim. Ind., School of Agr.

${ }^{s}$ Roman L Hruska U.S. Meat Anim. Res. Center, Agr. Res. Serv.

Received January 14, 1986.

Accepted April 17, 1986.
}

Although intact boars are more efficient and produce leaner carcasses than barrows (Charette, 1961; Field, 1971; Newell and Bowland, 1972), the occurrence of boar taint in fat and occasional management problems have prevented their marketability. A method that could take advantage of boar production yet avoid these disadvantages could significantly affect the swine industry.

Orchidectomy of domestic animals reduces sexual and(or) aggressive behavior, permits ease of management and allows marketing of younger males (Schanbacher and Ford, 1976). Surgical castration, however, has certain disadvantages, including the secondary consequences of hemorrhage and infection and acute or chronic setbacks on performance efficiency. Alternate methods of castration that would alleviate stress and other undesirable side effects are 
therefore of interest to those concerned with animal welfare.

Hypothalamic luteinizing hormone-releasing hormone (LHRH) released in to the hypophyseal portal blood vessels regulates the secretion of pituitary luteinizing hormone (LH) and follicle stimulating hormone (FSH). Interruption of either LHRH or LH action by active production of antibodies against these hormones inhibits function of the testes (Schanbacher 1984; Wickings and Nieschlag, 1984), thus producing castration-like effects.

The aim of the present study was to evaluate the effects of active immunization of boars against LHRH or LH on specific reproductive traits, rate of gain, presence of boar taint, carcass characteristics and other marketing aspects.

\section{Materials and Methods}

Animals. Forty crossbred boars (Yorkshire $\mathrm{x}$ Duroc $\times$ Spotted) were equally divided into eight groups. Four groups of boars were immunized against either LHRH in two different adjuvants or against ovine $\mathrm{LH}(\mathrm{OLH})$ or porcine LH (pLH). Two groups served as the adjuvant controls and two additional groups served as the castrate controls.

Immunization and Surgical Protocol. Luteinizing hormone-releasing hormone, conjugated to human serum globulin (LHRH-hSG) by the carbodiimide reaction (Fraser et al., 1974), was emulsified by sonication in equal volumes of sterile saline and complete Freund's adjuvant $(\mathrm{CFA})^{6}$ or in sterile saline and muramyldipeptide $(\mathrm{PEP})^{7}$ in squalene:arlacel $(4: 1, \mathrm{v}: \mathrm{v})$. Boars in Groups $I$ and II were immunized with $200 \mu \mathrm{g}$ LHRH-hSG in either CFA or PEP adjuvants, respectively, at $12 \mathrm{wk}$ of age. Two sc injections at the basal side of the left and right axillary regions were given. Boars were boosted $(200 \mu \mathrm{g}$ LHRH-hSG) using either incomplete Freund's adjuvant (IFA) or PEP at 16 and $18 \mathrm{wk}$ of age.

Porcine LH conjugated to hSG (pLH-hSG; $200 \mu \mathrm{g}$ ) was immulsified in sterile saline and CFA and administered sc to boars in Group III at 12 wk of age. Group IV boars were immunized with unconjugated OLH in CFA. Both groups were boosted $(200 \mu \mathrm{g})$ at 16 and $18 \mathrm{wk}$ of age.

\footnotetext{
${ }^{6}$ Difco Lab., Detroit MI.

${ }^{7}$ Sigma Chem. Co., St. Louis, MO.

${ }^{8}$ New England Nuclear, Boston, MA.
}

Boars in Groups $\mathrm{V}$ and VI served as the adjuvant controls and received $200 \mu \mathrm{g}$ hSG in CFA or hSG in PEP at 12 wk of age. Boosters in either IFA or PEP were given at 16 and 18 wk of age.

Boars in Groups VII (castrate weaning) and VIII (castrate booster) were castrated either at weaning or at $16 \mathrm{wk}$ of age when immunized boars received their first booster injections, respectively. The boars were manually restrained and the testes surgically removed.

Blood Samples. Anterior vena cava blood samples were drawn at 12,16, 18, 20 and 22 wk of age. All pigs were slaughtered at $24 \mathrm{wk}$ of age.

Hormone Assays. Plasma concentrations of LH (Niswender et al., 1970) and testosterone (Falvo and Nalbandov, 1974) were determined in duplicate $200 \mu$ l samples by previously described radioimmunoassay procedures. Sensitivities for the respective assays were 10 $\mathrm{pg} /$ tube for LH (LER-786-3, which has an LH biological activity of $.65 \times$ NIH-LH-S1 U/mg) and $10 \mathrm{pg} /$ tube for testosterone (T).

Antibody Titers to LHRH. Antibody titers to LHRH in boars immunized against LHRHhSG in CFA and PEP adjuvants and the CFA and PEP controls were determined on wk 12, $16,18,20$ and 22 , as described by Schanbacher (1982). Plasma from each of the immunized boars was diluted 1:1,000 with phosphatebuffered saline containing .2\% gelatin. The diluted plasma was placed in culture tubes with $20,000 \mathrm{cpm}$ of ${ }^{125}$ I-LHRH (100 $\mu$; approx. $1,500 \mathrm{Ci} / \mathrm{mmol}$ ) and incubated overnight at 4 C. The radioiodinated LHRH used for binding was prepared by reacting $2.5 \mu \mathrm{g}$ LHRH with .5 $\mathrm{mCi}$ of ${ }^{125} \mathrm{I}^{8}$ and $4 \mu \mathrm{g}$ chloramine T. Monoiodinated LHRH was separated from the other reaction products by QAE Sephadex chromatography (Nett and Adams, 1977). Free and bound ${ }^{125}$ I-LHRH were separated by the addition of $100 \mu$ dextran-coated charcoal. Following centrifugation, the supernatants were transfered to culture tubes and radioactivity was determined. Nonspecific binding, determined for the preimmunization pool for each boar, was subtracted to estimate the percentage of ${ }^{125}$ I-LHRH specifically bound $\left(\% \mathrm{~B} / \mathrm{B}_{0}\right)$ in plasma of LHRH-immunized boars.

LH Antibody Titers. Antibody titers to LH were determined in plasma pools from boars immunized against pLH-hSG, oLH and CFA adjuvant controls. Plasma pools from each of the immunized boars were diluted 1:100 with 
1:400 normal rabbit serum. Diluted plasma (100 $\mu \mathrm{l}$ in duplicate, final dilution 1:1,000) was placed in culture tubes with $20,000 \mathrm{cpm}$ of ${ }^{125} \mathrm{~A}-\mathrm{pLH}$ and incubated overnight at $4 \mathrm{C}$. The radioiodinated $\mathrm{pLH}$ used for binding was prepared by reacting $2.5 \mu \mathrm{g} \mathrm{pLH}$ with $.5 \mathrm{mCi}$ of ${ }^{125}$ I with $2.5 \mu \mathrm{g}$ chloramine T. Iodinated $\mathrm{LH}$ was separated from other reaction products by Biogel P-60 column chromatography. Free and bound ${ }^{125} \mathrm{I}-\mathrm{pLH}$ was separated by the addition of anti-gamma globulin. Following centrifugation the supernatants were aspirated. The pellets were counted and the specific $\mathrm{LH}$ binding was determined, as described for LHRH.

Testis and Accessory Gland Weights and Histology. Testis, seminal vesicle, cowper's and prostatic weights were recorded. Representative histologic sections were prepared on all tissues by fixing in buffered formalin, dehydrating in alcohol and xylene, sectioning at $6 \mu \mathrm{m}$ and staining with hematoxylin and eosin.

Performance and Carcass Traits. At slaughter (24 wk of age) hot carcass weights were recorded. After chilling, 10th rib backfat, carcass length and area of the longissimus dorsi were measured (Christian et al., 1967). Fat depth was measured opposite a point three-fourth the width of the longissimus from the chine bone between the 10th and 11th ribs (Fahey et al., 1977).

Boar Taint. Fat samples were collected from each boar and stored at $-20 \mathrm{C}$ for boar taint detection. The method of Cliplet and Strain (1980), as modified by Schanbacher et al. (1985), was used for boar taint analysis.

Statistics. Data were analyzed by leastsquares analysis of variance and corresponding F-test (Dixon and Massey, 1969). Post hoc comparisons of means were done by Tukey (Kirk, 1968) and Scheffe tests (Scheffe, 1959). Data were analyzed by the General Linear Model procedure of the Statistical Analysis System (SAS, 1982).

\section{Results}

Antibody titers against LHRH in boars immunized against LHRH-hSG using either CFA or PEP adjuvants (Groups I and II) and the adjuvant control boars (Groups V and VI) are shown in table 1 . Antibody titers in boars immunized against LHRH (Groups I and II) were nondetectable on wk 12 (week of immunization). On the day of the first booster injection (wk 16) antibody titers were detectable but prior to administration of the second booster (wk 18) titers rose and remained high through wk 22. There was no difference in antibody titers between LHRH-CFA and LHRH-PEP treated boars. Antibody titers for LHRH were nondetectable in the control CFA and PEP adjuvant-treated boars.

Antibody titers against $\mathrm{LH}$ were determined on wk 12 and 22 in boars immunized against pLH-hSG and oLH in CFA (Groups III and IV respectively) and in CFA adjuvant control boars (Group V). Two boars in Group III and three boars in Group IV showed specific binding near $10 \%$; all other boars presented nondetectable titers.

Plasma LH was determined in all samples on wk 12 and 22, except for those boars immunized against PLH-hSG or oLH (table 2). By wk 22, plasma LH in the LHRH-immunized boars (Groups I and II) was nondetectable. As expected, plasma LH levels increased in castrate

TABLE 1. LHRH ANTIBODY TITERS ${ }^{a}$ IN BOARS IMMUNIZED AGAINST LHRH-hSG OR hSG IN EITHER COMPLETE FREUND'S (CFA) OR MURAMYLDIPEPTIDE (PEP) ADJUVANTS ${ }^{b}$

\begin{tabular}{llllll} 
& \multicolumn{5}{c}{ Week } \\
\cline { 2 - 6 } Treatment & 12 & 16 & 18 & 20 & 22 \\
\hline LHRH-hSG + CFA & ND & $14.8 \pm 3.8$ & $61.4 \pm 3.1$ & $76.0 \pm 2.5$ & $72.1 \pm 2.6$ \\
LHRH-hSG + PEP & ND & $13.2 \pm 2.5$ & $64.9 \pm 3.1$ & $76.6 \pm 2.9$ & $70.1 \pm 5.1$ \\
CFA + hSG & ND & ND & ND & ND & ND \\
PEP + hSG & ND & ND & ND & ND & ND \\
\hline
\end{tabular}

\footnotetext{
${ }^{a}$ Percent of ${ }^{125}$ I-L.HRH binding in plasma diluted $1: 1,000$.

${ }^{b}$ All values are reported as the mean $\pm S E$ for five boars.

${ }^{c} \mathrm{ND}=$ nondetectable ( $<3 \%$ binding at $1: 100$ dilution).
} 
TABLE 2. PLASMA LH (PG/ML) IN BOARS IMMUNIZED AGAINST LHRH-hSG IN COMPLETE FREUND'S (CFA) OR MURAMYLDIPEPTIDE (PEP) ADJUVANTS' CFA + hSG OR PEP + hSG (ADJUVANT CONTROLS), AND CASTRATED EITHER AT THE TIME OF WEANING (CASTRATE. WEANING) OR AT 16 WK WHEN BOARS WERE BOOSTED (CASTRATE BOOSTER) ${ }^{a}$

\begin{tabular}{lllr}
\hline & & & Week \\
\cline { 3 - 4 } Treatment & Group & 12 & 22 \\
\hline LHRH-hSG + CFA & I & $102 \pm 13.9$ & ND $^{\mathrm{b}}$ \\
LHRH-hSG + PEP & II & $182 \pm 44.1$ & ND \\
CFA + hSG & V & $144 \pm 14.3$ & $70 \pm 10.0$ \\
PEP + hSG & VI & $158 \pm 33.3$ & $84 \pm 12.4$ \\
Castrate weaning & VIl & $202 \pm 12.0$ & $170 \pm 15.8$ \\
Castrate booster & VIII & $140 \pm 32.1$ & $178 \pm 41.8$ \\
\hline
\end{tabular}

${ }^{a}$ All values are reported as the mean $\pm \mathrm{SE}$ for five boars.

$\mathrm{b}_{\mathrm{ND}}=$ nondetectable.

controls (Groups VII-VIII) relative to adjuvant controls (Groups V and VI).

Plasma testosterone levels in all boars are shown in table 3 . In castrated boars testosterone levels were nondetectable. When compared with adjuvant controls, the LHRH-immunized boars showed a significant reduction in plasma $T$ $(\mathrm{P}<.05)$ by wk 18 ( $2 \mathrm{wk}$ after the first booster injection) and remained low for the duration of the experiment. Boars immunized against LH did not show plasma $T$ values significantly different from adjuvant controls.

The paired testes weights and accessory sex gland weights for the various treatment groups are shown in table 4 . The weights of the testes, and accessory sex glands were reduced $(P<.05)$ in all the LHRH-immunized groups as compared with intact controls, regardless of the adjuvant employed by the termination of the experiment. Whereas pLH-hSG treated boars did not show any significant effect on testicular weighr, all accessory sex glands were significantly reduced as compared with adjuvant controls. Immunization against oLH had no significant effect on any characteristic measured.

The histological appearance of the testes and seminal vesicles from control and LHRH immunized boars is shown in figure 1 . Note the lack of spermatids in the testes from an immunized boar $(B, D)$ as compared with a

TABLE 3. PLASMA TESTOSTERONE (NG/ML) IN BOARS IMMUNIZED AGAINST L.HRH-hSG IN COMPLETE FRFUND'S (CFA) OR MURAMYLDIPEPTIDE (PEP) ADJUVANTS, PLH-hSG OR OLH IN CFA, ADJUVANT CONTROLS, AND CASTRATED EITHER AT THE TIME OF WEANING (CASTRATE WEANING) OR AT 16 WK WHEN BOARS WERE BOOSTED (CASTRATE BOOSTER) ${ }^{\mathrm{a}}$

\begin{tabular}{|c|c|c|c|c|c|c|c|}
\hline \multirow[b]{2}{*}{ Treatment } & \multirow[b]{2}{*}{ Group } & \multicolumn{6}{|c|}{ Week } \\
\hline & & 12 & 14 & 16 & 18 & 20 & 22 \\
\hline LHRH-hSG CFA & ] & $3.2 \pm 1.5^{\mathrm{cd}}$ & $.7 \pm .2$ & $.9 \pm .2^{c d}$ & $.3 \pm .1^{\mathrm{d}}$ & $N D^{\text {be }}$ & $N^{e}$ \\
\hline LHRH-hSG PEP & II & $.8 \pm .4 \mathrm{~cd}$ & $.3 \pm .1$ & $.9 \pm .2^{\mathrm{cd}}$ & $.3 \pm .2^{\mathrm{d}}$ & $\mathrm{ND}^{\mathrm{e}}$ & $\mathrm{ND}^{\mathrm{e}}$ \\
\hline pLH-hSG & III & $2.1 \pm .8^{\mathrm{cd}}$ & $.6 \pm .5$ & $1.2 \pm .4^{\mathrm{cd}}$ & $1.4 \pm .1^{\mathrm{e}}$ & $.4 \pm .1 \mathrm{de}$ & $1.6 \pm .8^{\mathrm{de}}$ \\
\hline OLH & IV & $2.7 \pm .8^{\mathrm{cd}}$ & $.6 \pm .3$ & $1.4 \pm .3^{c}$ & $1.8 \pm .3^{c}$ & $.7 \pm .2^{\mathrm{cd}}$ & $5.3 \pm 1.2^{\mathrm{d}}$ \\
\hline $\mathrm{CFA}+\mathrm{hSG}$ & $\mathrm{V}$ & $1.9 \pm .6^{\mathrm{cd}}$ & $.8 \pm .6$ & $.7 \pm .2^{\mathrm{cd}}$ & $1.7 \pm .6^{\mathrm{c}}$ & $1.0 \pm .1^{c}$ & $5.7 \pm .9^{\mathrm{cd}}$ \\
\hline$P E P+h S G$ & VI & $2.3 \pm 1.0^{\mathrm{cd}}$ & $.3 \pm .1$ & $.7 \pm .2^{c d}$ & $1.6 \pm 3.5^{\mathrm{ce}}$ & $.8 \pm .2^{\mathrm{cd}}$ & $10.3 \pm 2.5^{\mathrm{cd}}$ \\
\hline Castrate weaning & VII & $\mathrm{ND}^{\mathrm{C}}$ & $.2 \pm .1$ & $N D^{d}$ & $N D^{d}$ & $N D^{e}$ & $\mathrm{ND}^{\mathrm{e}}$ \\
\hline Castrate booster & VIII & $4.7 \pm 1.3^{\mathrm{d}}$ & $.9 \pm .3$ & $\mathrm{ND}^{\mathrm{d}}$ & $\mathrm{ND}^{\mathrm{d}}$ & $\mathrm{ND}^{\mathrm{e}}$ & $\mathrm{ND}^{\mathrm{e}}$ \\
\hline
\end{tabular}

\footnotetext{
${ }^{\mathrm{a}} \mathrm{All}$ values reported as mean $\pm \mathrm{SE}$ for five boars.

$\mathrm{b}_{\mathrm{ND}}=$ nondetectable.

$c, d, e$ Values without common superscripts differ $(P<.05)$ within age group.
} 
TABLE 4. PAIRED TESTES, SEMINAL VESICLES, COWPER'S AND PROSTATIC GLAND WEIGHTS (GM)

IN BOARS IMMUNIZED AGAINST LHRH-hSG IN COMPLETE FREUND'S (CFA)

OR MURAMYLDIPEPTIDE (PEP) ADJUVANTS, pLH-hSG OR OLH IN CFA,

ADJUVANT CONTROLS, AND CASTRATED EITHER AT THE TIME OF

WEANING (CASTRATE WEANING) OR AT 16 WK WHEN BOARS WERE BOOSTED (CASTRATE BOOSTER) ${ }^{a}$

\begin{tabular}{|c|c|c|c|c|c|}
\hline Treatment & Group & Testes & Seminal vesicles & Cowper's & Prostate \\
\hline LHRH-hSG CFA & I & $180 \pm 29^{b}$ & $8 \pm 1^{b}$ & $21 \pm 4.3^{b}$ & $.6 \pm .1 \mathrm{~b}$ \\
\hline LHRH-hSG PEP & II & $163 \pm 39^{b}$ & $4 \pm 1.1^{b}$ & $15 \pm 2.5^{\mathrm{b}}$ & $.6 \pm .1 \mathrm{~b}$ \\
\hline pLH-hSG CFA & III & $437 \pm 109$ & $39 \pm 10.7^{b}$ & $81 \pm 23.6^{b}$ & $5.2 \pm 1.6^{b}$ \\
\hline OLH CFA & IV & $591 \pm 58$ & $104 \pm 28.1$ & $142 \pm 16.8$ & $7.4 \pm 1.8$ \\
\hline $\mathrm{CFA}+\mathrm{hSG}$ & V & $557 \pm 43$ & $103 \pm 6.9$ & $189 \pm 14.6$ & $12.4 \pm 1.4$ \\
\hline $\mathrm{PEP}+\mathrm{hSG}$ & VI & $608 \pm 35$ & $132 \pm 14.9$ & $150 \pm 12.5$ & $11.7 \pm 1.6$ \\
\hline Castrate weaning & VII & & $3 \pm .4 b$ & $6 \pm .9 b$ & $.8 \pm .2 b$ \\
\hline Castrate booster & VIII & & $5 \pm .5^{b}$ & $11 \pm .9^{b}$ & $.9 \pm .1^{b}$ \\
\hline
\end{tabular}

${ }^{a}$ All values reported as mean $\pm S E$ for five boars.

${ }^{b}$ Different $(P<.05)$ from CFA and PEP controls.

control $(A, C)$. Also shown are sections of the seminal vesicle from a control $(E)$ and treated (F) boar. Note the highly developed secretory epithelium of the control compared with the atrophic epithelium of the LHRH immunized boar.

Average daily gains (ADG) are presented in table 5. As indicated, the only difference found was at wk 12, when the castrate booster boars (Group VIII) had a lower ADG than boars in Groups I, IV, VI and VII. Table 6 shows the carcass characteristics for each group of boars. The boars were raised to a heavy slaughter weight to allow for development of boar taint. The only differences in slaughter weight and hot carcass weight (HCW) among treatment groups was in the castrate booster boars (Group VIII), which were lighter than Groups I, IV and VII. The difference in HCW was correlated to differences in slaughter weights. There were no differences in loin eye area. Backfat measurements over the 10th rib indicated that the LHRH-CFA treated boars (Group I) had more $(\mathrm{P}<.05)$ backfat that boars in Groups III, V, VI, VII and VIII. Table 6 also shows the average score for boar taint measurements. The intact

TABLE 5. AVERAGE DAILY GAINS (KG/D) IN BOARS IMMUNIZED AGAINST LHRH-hSG IN COMPLETE FREUND'S (CFA) OR MURAMYLDIPEPTIDE (PEP) ADJUVANTS, pLH-hSG OR oLH IN CFA, ADJUVANT CONTROLS, AND CASTRATED EITHER AT THE TIME OF WEANING (CASTRATE WEANING) OR AT 16 WK WHEN BOARS WERE BOOSTED (CASTRATE BOOSTER) ${ }^{\mathbf{a}}$

\begin{tabular}{lllllcrc}
\hline & & \multicolumn{5}{c}{ Experimental period (age in weeks) } \\
\cline { 3 - 8 } Treatment & Group & 8 & 12 & 16 & 20 & 24 & Overall \\
\hline LHRH-hSG CFA & I & $.48 \pm .02$ & $.77 \pm .05^{\mathrm{b}}$ & $.88 \pm .02$ & $1.23 \pm .04$ & $1.07 \pm .05$ & $.88 \pm .02$ \\
LHRH-hSG PEP & II & $.39 \pm .03$ & $.65 \pm .05^{\mathrm{bc}}$ & $.72 \pm .07$ & $1.02 \pm .06$ & $1.17 \pm .03$ & $.79 \pm .04$ \\
pLH-hSG CFA & III & $.40 \pm .02$ & $.68 \pm .07^{\mathrm{bc}}$ & $.93 \pm .05$ & $1.0 \pm .13$ & $.90 \pm .08$ & $.78 \pm .02$ \\
OLH CFA & IV & $.53 \pm .02$ & $.78 \pm .06^{\mathrm{b}}$ & $.85 \pm .12$ & $1.18 \pm .13$ & $.92 \pm .07$ & $.85 \pm .1$ \\
CFA + hSG & V & $.43 \pm .06$ & $.67 \pm .06^{\mathrm{bc}}$ & $.88 \pm .08$ & $.90 \pm .07$ & $1.02 \pm .04$ & $.79 \pm .05$ \\
PEP + hSG & VI & $.52 \pm .04$ & $.78 \pm .07^{\mathrm{b}}$ & $.86 \pm .05$ & $.95 \pm .08$ & $.93 \pm .03$ & $.83 \pm .04$ \\
Castrate weaning & VII & $.45 \pm .04$ & $.79 \pm .04^{\mathrm{b}}$ & $.90 \pm .08$ & $1.07 \pm .09$ & $1.02 \pm .04$ & $.84 \pm .02$ \\
Castrate booster & VIII & $.38 \pm .04$ & $.50 \pm .04^{\mathrm{c}}$ & $.80 \pm .06$ & $.91 \pm .12$ & $.84 \pm .31$ & $.68 \pm .12$ \\
\hline
\end{tabular}

${ }^{\text {a }}$ All values reported as mean \pm SE for five boars.

$\mathrm{b}, \mathrm{c}$ Values without common superscripts differ $(\mathbf{P}<.05)$. 


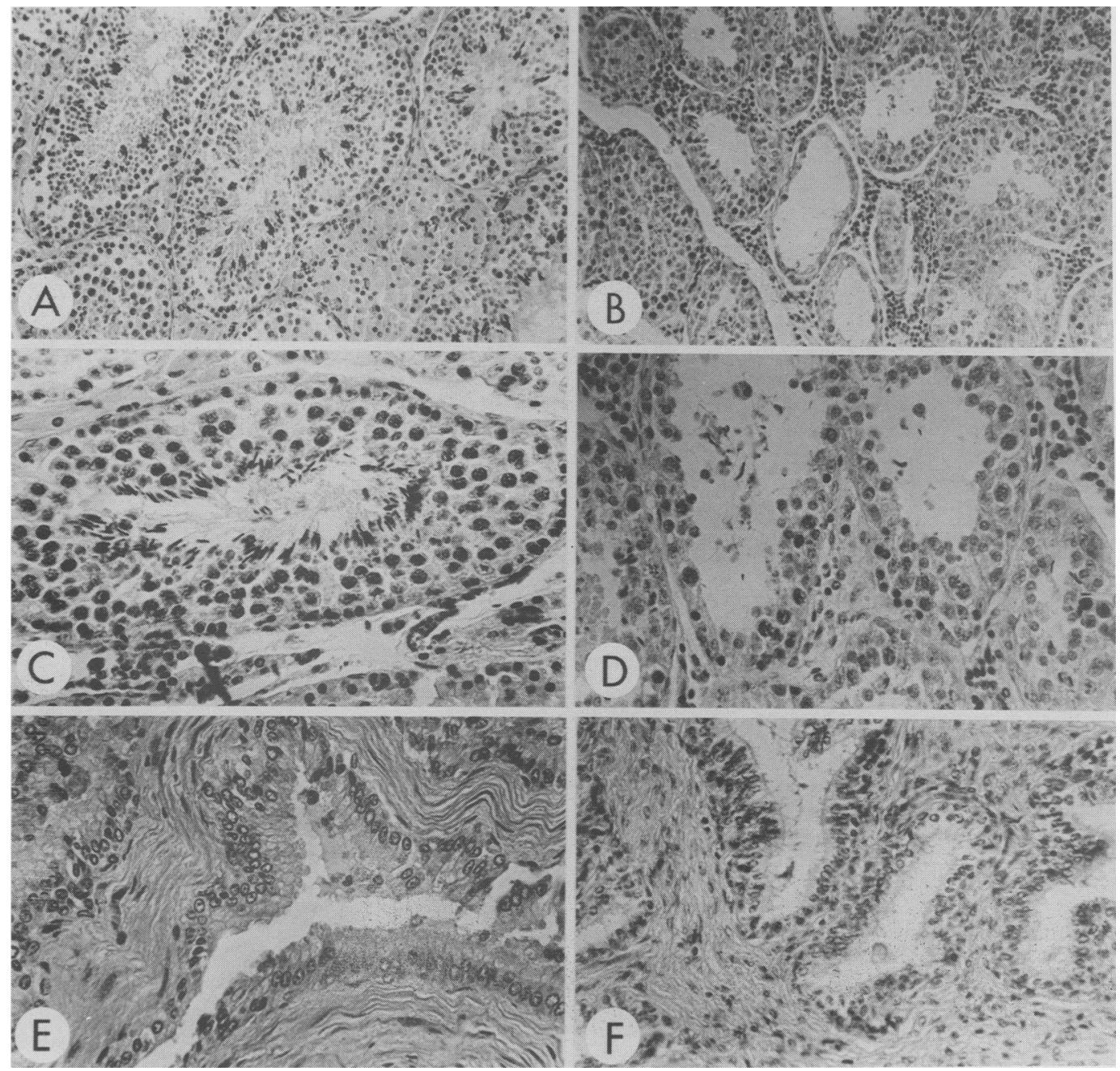

Figure 1. Light micrographs of the testes $(A=50 X ; C=100 \times)$ from a control boar showing expansion of the seminiferous tubules and germinal epithelium with spermatids present; and from the testes $(B=50 X ; D=$ $100 \times$ ) from a boar immunized against LHRH-hSG showing the disruption of the seminiferous epithelium and complete absence of post-meiotic germ cells. Light micrographs of the seminal vesicle $(E=50 \times)$ from a control boar showing the large acinar secretory units lined by columnar epithelium with apical granules and from the seminal vesicle $(F=100 \mathrm{X}$ ) from a boar immunized against $\mathrm{LHRH}$-hSG showing the atrophic cuboidal epithelium in an expanded interstitium.

control boars (Groups $\mathrm{V}$ and $\mathrm{VI}$ ) and the oLH-treated boars (Group IV) had a greater incidence $(\mathrm{P}<.05)$ of boar taint than boars in all other groups. Also there were no differences in the boar taint detected among boars in Groups I, II, III, VII and VIII. This would indicate the ability of active immunization against LHRH and pLH to cause castration-like effects and to reduce the incidence of boar taint.
The effectiveness of both adjuvants was equal in regard to enhancing antigenicity and not causing lesions at the injection sites.

\section{Discussion}

In spite of successful LHRH immunization of the rabbit (Arimura et al., 1973), rat (Fraser et al., 1974), dog (Schanbacher et al., 1983), marmoset monkey (Hodges and Hearn, 1977), 
TABLE 6. CARCASS CHARACTERISTICS AND BOAR TAINT IN BOARS IMMUNIZED AGAINST LHRH-hSG IN COMPLETE FREUND'S (CFA) OR MURAMYLDIPEPTIDE (PEP) ADJUVANTS, pLH-hSG OR OLH IN CFA, ADJUVANT CONTROLS, AND CASTRATED EITHER AT THE TIME OF WEANING (CASTRATE WEANING) OR AT 16 WK WHEN BOARS WERE BOOSTED (CASTRATE BOOSTER) ${ }^{\mathrm{a}}$

\begin{tabular}{|c|c|c|c|c|c|c|}
\hline Treatment & Group & $\begin{array}{l}\text { Slaughter } \\
\mathrm{wt}, \mathrm{kg}\end{array}$ & $\begin{array}{l}\text { Hot } \\
\text { carcass } \\
\text { wt, kg }\end{array}$ & $\begin{array}{l}\text { Loin } \\
\text { eye area } \\
\mathrm{cm}^{2}\end{array}$ & $\begin{array}{l}\text { Backfat } \\
\mathrm{cm}\end{array}$ & $\begin{array}{l}\text { Boar } \\
\text { taint }\end{array}$ \\
\hline LHRH-hSG CFA & I & $130.6 \pm 3.6^{\mathrm{b}}$ & $94.8 \pm 2.8^{b}$ & $40.0 \pm 1.8$ & $4.3 \pm .2^{b}$ & $.67 \pm .1^{b}$ \\
\hline LHRH-hSG PEP & II & $117.4 \pm 5.7^{b c}$ & $84.6 \pm 4.4^{b c}$ & $36.8 \pm 1.9$ & $3.4 \pm .3^{b c}$ & $1.10 \pm .2 \mathrm{~b}$ \\
\hline pLH-hSG CFA & III & $116.5 \pm 2.9^{b c}$ & $83.4 \pm 2.3^{b c}$ & $41.2 \pm 4.3$ & $3.2 \pm .2^{\mathrm{c}}$ & $1.30 \pm .2^{\mathrm{b}}$ \\
\hline OLH CFA & IV & $126.4 \pm 3.9^{b}$ & $92.1 \pm 3.8^{b}$ & $42.3 \pm 2.6$ & $3.5 \pm .1 \mathrm{bc}$ & $1.60 \pm .1^{\mathrm{c}}$ \\
\hline$C F A+h S G$ & V & $119.3 \pm 7.4^{b c}$ & $87.4 \pm 4.0^{\mathrm{bc}}$ & $43.0 \pm 3.4$ & $2.7 \pm .2^{\mathrm{c}}$ & $2.0 \pm .2^{c}$ \\
\hline $\mathrm{PEP}+\mathrm{hSG}$ & VI & $119.4 \pm 6.4 b c$ & $86.9 \pm 6.3^{b c}$ & $43.9 \pm 1.8$ & $3.2 \pm .3^{\mathrm{c}}$ & $1.80 \pm .2^{c}$ \\
\hline Castrate weaning & VII & $125.1 \pm 3.4^{b}$ & $92.5 \pm 3.1^{b}$ & $37.6 \pm 1.7$ & $2.8 \pm .2^{\mathrm{C}}$ & $.95 \pm .1 \mathrm{~b}$ \\
\hline Castrate booster & VIII & $100.7 \pm 4.3^{c}$ & $75.1 \pm 8.4^{\mathrm{C}}$ & $34.5 \pm 3.8$ & $2.7 \pm .3^{\mathrm{c}}$ & $1.0 \pm .1^{b}$ \\
\hline
\end{tabular}

${ }^{a}$ All values reported as mean $\pm \mathrm{SE}$ for five boars.

$\mathrm{b}, \mathrm{c}$ Values without common superscripts differ $(\mathrm{P}<.05)$.

rhesus monkey (Chappell et al., 1980), ram (Jeffcoate et al., 1982; Schanbacher, 1982), bull (Robertson et al., 1979; Schanbacher, 1985) and stallion (Schanbacher and Pratt, 1985), immunization effects on the boar have not been previously reported. Recently, however, it has been reported that active immunization against LHRH in gilts resulted in decreased plasma levels of gonadotropins and gonadal steroids, with cessation of estrous cyclicity (Esbenshade and Britt, 1985).

The present study describes the endocrine, histological, performance and carcass trait responses of boars to active immunization against LHRH, oLH and pLH. The results indicate that this species responds well to LHRH immunization. The antibody production in response to active immunization against pLH-hSG and oLH was more variable. When LHRH antibody titers reached high levels, which neutralized endogenous LHRH, plasma $\mathrm{LH}$ and $\mathrm{T}$ were reduced, resulting in atrophy of both the testes and sex accessory glands. To our knowledge this is the only reported study on successful LHRH immunization in the boar. Thus this species appears particularly susceptible to LHRH deprivation, as evidenced by gonadal regression in these studies. Our observations in the boar extend those in other species in which similar immunization protocols result in atrophy of the male reproductive system (Schanbacher, 1984).

The response of boars to immunization with pLH conjugated to human serum globulin resulted in partial success. Whereas the testicular weight was not affected, there was reduction in plasma $T$ with concomitant reduction in accessory sex gland weight. Plasma LH levels in these samples were not determined because of the presence of $\mathrm{LH}$ antibodies, which likely would have interfered in the assay. Immunization against oLH failed to affect any parameter measured; perhaps because it was not conjugated to a carrier protein so as to make it more antigenic.

Our results using pLH-hSG agree with other studies in which active immunization against LH was shown to cause a decrease in serum $T$ in rabbits and rats (Wakabayashi and Tamoaki, 1966), dogs (Lunnen et al., 1974) and goats (Hayashida and Farook, 1969). Immunization of male (Pineda et al., 1967) and female (Pineda et al., 1968) rabbits against bovine LH was associated with atrophy of the gonads and accessory sex organs. Immunization with $\mathrm{oLH}$ did not cause atrophy of the boar reproductive tract, perhaps because of insufficient antibody production.

Average daily gains were not affected by our immunization procedures. These results are in agreement with Charette (1961), Lidvall et al. (1964), Field (1971) and Newell and Bowland (1972), who concluded that there was no difference in ADG when comparing boars and barrows. However, the findings of Walstra and Kroeske (1968) and Walstra et al. (1978) are contradictory to our data and indicated that barrows grew significantly faster than boars 
when fed ad libitum. Seideman et al. (1982) indicated that the effect of castration on growth in boars is not as great as in bulls and rams.

The data regarding backfat, loin eye area and $\mathrm{HCW}$ are in contrast to most other reports. Seideman et al. (1982), in their review, indicated that boars have larger loin eyes and less backfat than barrows. The boars in the two intact adjuvant control groups (V and VI) and the treatment groups in which there was little or no castration effect (Groups III and IV) tended to have larger loin eye areas. Lawrie et al. (1964) reported that barrows had more muscle fat than boars at $90 \mathrm{~kg}$ but there was a tendency for a reversal of this effect of $130 \mathrm{~kg}$. The difference in backfat at lower weights may tend to decrease at higher weights.

The results of this study indicate that immunization against LHRH and $\mathrm{pLH}$, when conjugated to hSG, decreased the incidence of boar taint but had no consistent effect on performance (backfat may be an exception). Although these results are preliminary in nature, they provide a basis on which to explore further the possibility of immunoneutralization as both a feasible and practical alternative to surgical castration in boars.

Immunocastration seems particularly atractive to the livestock industry. Inhibition of testicular development and suppression of testosterone secretion in young ram lambs have been achieved by active immunization against LHRH (Schanbacher, 1982). Bull calves are more variable in their response to $\mathrm{LHRH}$ immunization, with some calves responding with the production of LHRH antibodies and testicular involution (Robertson et al., 1982). The removal of testicular influence during certain phases of the growing period in lambs and calves can affect body composition (Robertson et al., 1982; Schanbacher, 1982) and thereby provide the livestock producer with timely management alternatives not previously realized. Further work is needed in the boar to determine if LHRH immunoneutralization is indeed a practical and acceptable alternative to orchiectomy by the swine producer.

In conclusion, we have observed that following an initial immunization and two boosters with LHRH-hSG, high titers of anti-LHRH were generated in the boar. These high titers, which were detected within 2 wk from the first booster administration, remained high for an additional $4 \mathrm{wk}$ following the second booster.
Our data do not allow for us to speculate on the chronic effect of such an immunization schedule; however, repeated boosters might be necessary to maintain high antibody titers. Our results are of special interest because of the complete success observed in boars immunized with LHRH-hSG (regardless of adjuvant employed). Our data clearly demonstrate for the first time, profound effects of LHRH immunoneutralization on the reproductive system of the boar. These results indicate that active immunization against LHRH is not only practical, but may provide a feasible and economical method of orchiectomy to enhance meat production by the pork industry.

\section{Literature Cited}

Arimura, A., H. Sato, T. Kumaska, R. B. Worobec, L. Debekjuk, J. Dunn and A. V. Schally. 1973. Production of antiserum to LH-releasing hormone (LHRH) associated with gonadal atrophy in rabbits: development of radioimmunoassays for LH-RH. Endocrinology 93:1092.

Chappell, S. C., W. E. Ellinwood, C. Huckins, D. C. Herbert, and H. G. Spies. 1980. Active immunization against male rhesus monkeys against luteiniz ing hormone-releasing hormone. Biol, Reprod. $22: 333$

Charette, L. A. 1961. The effect of sex and age of males at castration on growth and carcass quality of yorkshire swine. Can. J. Anim. Sci. 41:30.

Christian, J. A., R. H. Ingram, M. D. Judge, R. A. Merkel, C. E. Shelby, J. R. Stouffer and C. L. Strong. 1967. Guides for pork carcass evaluation. In: Recommended Guides for Carcass Evaluation and Contests. Amer. Meat Sci. Assoc., Chicago, IL.

Cliplet, R. L. and J. H. Strain. 1980. Relationship of sex odor to panel acceptability and certain other organoleptic characteristics of pork chops. Can. J. Anim. Sci. $61: 45$.

Dixon, W. J. and F. J. Massey. 1969. Introduction to Statistical Analysis. McGraw Hill, Inc., New York, NY.

Esbenshade, K. L. and J. H. Britt. 1985. Active immunization of gilts against gonadotropinreleasing hormone: Effects on secretion of gonadotropins, reproductive function, and responses to agonists of gonadotropin-releasing hormone. Biol. Reprod. 33:569.

Fahey, T. J., D. M. Schaefer, R. G. Kaufman, R. J. Epley, P. F. Gould, J. R. Romans, G. C. Smith and D. G. Topel. 1977. A comparison of practical methods to estimate pork carcass composition. J. Anim. Sci. 44:4.

Falvo, R. E. and A. V. Nalbandov. 1974. Radioimmunoassay of peripheral plasma testosterone in males from eight species using a specific antibody without chromatography. Endocrinology 95:1466.

Field, R. A. 1971. Effect of castration on meat quality and quantity. J. Anim. Sci. 32:849. 
Fraser, H. M., A. Gunn, S. L. Jeffcoate and D. T. Holland. 1974. Effect of active immunization to luteinizing hormone-releasing hormone on serum and pituitary gonadotropins, testes and accessory sex organs in the male rat. Endocrinology 63:399.

Hayashida, T. and A. Farook. 1969. Ovine gonadotrophic hormone injections leading to autoimmunity in goats. Gen. Comp. Endocrinol. $12: 124$.

Hodges, J. K. and J. P. Hearn. 1977. Effects of immunisation against luteinizing hormone releasing hormone on reproduction of the marmoset monkey Callitrix jacchus. Nature 265:474.

Jeffcoate, I. A., J.M.S. Lucas and D. B. Crighton. 1982. Effects of active immunization of ram lambs and bull calves against synthetic luteinizing hormone releasing hormone. Theriogenology $18: 65$.

Kirk, R. E. 1968. Experimental design: Procedures for the behavioral sciences. Brooks/Cole Publishing Co., Belmont, CA.

Lawrie, R. A., R. W. Pomerory and A. Cuthberston. 1964. Studies on the muscles of meat animals. 6 . Comparative composition of various muscles in boars of two weight groups in relation to hogs. $J$. Agr. Sci. (Camb.) 63:385.

Lidvall, E. R., C. R. Burgess, C. B. Ramsey and J. W. Cole. 1964. Performance and carcass characteristics of boars, barrows and gilts. J. Anim. Sci. 23:851

Lunnen, J. E., L. C. Faulkner, M. L. Hopwood and B. W. Pickett. 1974. Immunization of dogs with bovine luteinizing hormone. Biol. Reprod. $10: 453$.

Nett, T. M. and T. E. Adams. 1977 Further studies on the radioimmunoassay of gonadotropin-releasing hormone: Effect of radioiodination, antiserum and unextracted serum on levels of immunoreactivity in serum. Endocrinology 101:1135.

Newell, J. A. and J. P. Bowland. 1972. Performance, carcass composition and fat composition of boars, gilts, and barrows fed two levels of protein. Can. J. Anim. Sci. 52:543.

Niswender, G. D. L. E. Reichert and D. R. Zimmerman. 1970. Radioimmunoassay of serum levels of luteinizing hormone throughout the estrous cycle of pigs. Endocrinology 87:576.

Pineda, M. H., L. C. Faulkner, M. L. Hopwood and D. C. Leuker. 1968. Effects of immunizing female rabbits with bovine luteinizing hormone. Proc. Soc. Exp. Biol. Med, 128:743.

Pineda, M. H., D. C. Leuker, L. C. Faulkner and M. L. Hopwood. 1967. Atrophy of rabbit testes associated with production of antiserum to bovine luteinizing hormone. Proc. Soc. Exp. Biol. Med. 125:665.

Robertson, I. S., H. M. Fraser, G. M. Innes and A. S. Jones. 1982. Effect of immunological castration on sexual and reproductive characteristics in male cattle. Vet. Rec. 111:529.

Robertson, I. S., J. C. Wilson and H. M. Fraser. 1979. Immunological castration in male cattle. Vet. Rec. 105:556.

SAS. 1982. SAS User's Guide: Statistics. Statistical Analysis System Institute, Inc. Cary, NC.

Schanbacher, B. D. 1982. Responses of ram lambs to active immunization against testosterone and luteinizing hormone-releasing hormone. Amer. J. Physiol. 242:E201.

Schanbacher, B. D. 1984. Active immunization against LH-RH in the male. In: B. D. Crighton (Ed.) Immunological Aspects of Reproduction in Mammals. pp 345-362. Butterworths, London.

Schanbacher, B. D. 1985. Effect of active immunization of the ram and bull against luteinizing hormone. Theriogenology 24:59.

Schanbacher, B. D., H. F. English, D. Gross, R. J Santen, M. F. Walker, and R. E. Falvo. 1983. Animal model of isolated gonadotropin deficiency. I. Hormonal responses to LHRH immunoneutralization. J. Androl. 4:233.

Schanbacher, B. D. and J. J. Ford. 1976. Luteinizing hormone, testosterone, growth and carcass responses to sexual alteration in the ram. J. Anim. Sci. 43:638.

Schanbacher, B. D. and B. R. Pratt. 1985. Response of a cryptorchid stallion to vaccination against luteinizing hormone releasing hormone. Vet. Rec. 116:74.

Schanbacher, B. D., J. T. Yen and W. G. Pond. 1985. Testosterone and the incidence of boar taint: Effects of testosterone or testosterone propionate on the incidence of boar taint in implanted barrows. Meat Sci. 13:237.

Scheffe, H, 1959. The Analysis of Variance. John Wiley Co., Inc., New York, NY.

Seideman, S. C., H. R. Cross, R. R. Oltjen and B. D. Schanbacher. 1982. Utilization of the intact male for red meat production: A review. J. Anim. Sci. $55: 826$.

Wakabayashi, K. and B. Tamaoki. 1966. Influence of immunization with luteinizing hormone upon anterior pituitary-gonadal system of rats and rabbits with special reference to histological changes and biosynthesis of luteinizing hormone and steroids. Endocrinology 79:477.

Walstra, P., G. A. Buiting and G. Mateman. 1978. Fattening of boars. I: Influence of castration and feeding method on growth, food conversion and carcass quality. Anim. Breed. Abstr. 46:440.

Walstra, P. and D. Kroeske. 1968. The effect of castration on meat production in male pigs. World Rev. Anim. Prod. 4:59.

Wickings, E. J, and E. Nieschlag. 1984. Effects of immunization against gonadotropins on male reproductive function. In: B. D. Crighton (Ed.) Immunological Aspects of Reproduction in Mammals. pp 419-426. Butterworths, London. 